\title{
A Review on Erythropietin in Pregnancy
}

\author{
Obeagu Emmanuel Ifeanyi ${ }^{1 *}$ and Obeagu Getrude Uzoma² \\ ${ }^{1}$ Department of University Health Services, Michael Okpara University of Agriculture, Nigeria \\ ${ }^{2}$ Department of Nursing Science, Ebonyi State University, Nigeria
}

Submission: January 26, 2018; Published: February 12, 2018

${ }^{*}$ Corresponding author: Obeagu Emmanuel Ifeanyi, Department of University Health Services, Michael Okpara University of Agriculture, Nigeria, Email: emmanuelobeagu@yahoo.com

\begin{abstract}
Erythropoietin, also known as EPO, is a glycoprotein hormone that controls erythropoiesis, or red blood cell production. It is a cytokine for erythrocyte precursors in the bone marrow. Also called haematopoietin or haemopoietin, it is produced by interstitial fibroblasts in the kidney in close association with peritubular capillary and proximal convoluted tubule. It is also produced in perisinusoidal cells in the liver. While liver production predominates in the fetal and perinatal period, renal production is predominant during adulthood. The primary role of erythropoietin is an essential hormone for red blood cell production. Without it, definitive erythropoiesis does not take place. Under hypoxic conditions, the kidney will produce and secrete erythropoietin to increase the production of red blood cells by targeting CFU-E, proerythroblast and basophilic erythroblast subsets in the differentiation. Erythropoietin has its primary effect on red blood cell progenitors and precursors. Changes in circulatory system during pregnancy affect renal function, due to physiological increase in blood volume. Renal blood flow and glomerular filtration increase by $30-50 \%$, and because erythropoietin is of renal origin, EPO concentration has been proved to increase 2-4-folds in the course of pregnancy and plateau is achieved after 20 weeks during the second trimester of pregnancy.
\end{abstract}

Keywords: Erythropietin; Pregnancy; Haematopoietin

Abbreviations: ESA: Erythropoiesis-Stimulating Agents; EpoR: Erythropoietin Receptor; CFU-E: Colony-Forming Unit-Erythroid; BFU-E: BurstForming Unit-Erythroid; rHuEPO: Recombinant Human Erythropoietin

\section{Erythropoietin}

Erythropoietin, also known as EPO, is a glycoprotein hormone that controls erythropoiesis, or red blood cell production. It is a cytokine (protein signaling molecule) for erythrocyte (red blood cell) precursors in the bone marrow. Human EPO has a molecular weight of $34 \mathrm{kDa}[1]$.

Also called haematopoietin or haemopoietin, it is produced by interstitial fibroblasts in the kidney in close association with peritubular capillary and proximal convoluted tubule. It is also produced in perisinusoidal cells in the liver. While liver production predominates in the fetal and perinatal period, renal production is predominant during adulthood. In addition to erythropoiesis, erythropoietin also has other known biological functions. For example, it plays an important role in the brain's response to neuronal injury. EPO is also involved in the wound healing process [2].

Exogenous erythropoietin is produced by recombinant DNA technology in cell culture. Several different pharmaceutical agents are available with a variety of glycosylation patterns, and are collectively called erythropoiesis-stimulating agents (ESA). The specific details for labeled use vary between the package inserts, but ESAs have been used in the treatment of anaemia in chronic kidney disease, anaemia in myelodysplasia, and in anaemia from cancer chemotherapy. Boxed warnings include a risk of death, myocardial infarction, stroke, venous thromboembolism, and tumor recurrence. Exogenous erythropoietin has been used illicitly as a performance-enhancing drug; it can often be detected in blood, due to slight differences from the endogenous protein, for example, in features of post-translational modification.

\section{Function of Erythropoietin}

\section{Red blood cell production}

The primary role of erythropoietin is an essential hormone for red blood cell production. Without it, definitive erythropoiesis does not take place. Under hypoxic conditions, the kidney will produce and secrete erythropoietin to increase the production of red blood cells by targeting CFU-E, proerythroblast and basophilic erythroblast subsets in the differentiation. Erythropoietin has its primary effect on red blood cell progenitors and precursors (which are found in the bone marrow in humans) by promoting their survival through protecting these cells from apoptosis.

Erythropoietin is the primary erythropoietic factor that cooperates with various other growth factors (e.g., IL-3, IL-6, glucocorticoids, and SCF) involved in the development of erythroid lineage from multipotent progenitors. The burst-forming unit- 
erythroid (BFU-E) cells start erythropoietin receptor expression and are sensitive to erythropoietin. Subsequent stage, the colony-forming unit-erythroid (CFU-E), expresses maximal erythropoietin receptor density and is completely dependent on erythropoietin for further differentiation. Precursors of red cells, the proerythroblasts and basophilic erythroblasts, also express erythropoietin receptor and are therefore affected by it.

\section{Non haematopoietic roles of erythropoietin}

Erythropoietin has a range of actions including vasoconstriction-dependent hypertension, stimulating angiogenesis, and inducing proliferation of smooth muscle fibers. It can increase iron absorption by suppressing the hormone hepcidin [3].

EPO levels of 100 times the baseline have been detected in brain tissue as a natural response to hypoxic damage [4]. In rats, pretreatment with erythropietin was associated with neuronal protection during induced cerebral hypoxia. Trials in humans have not been reported [1].

Multiple studies have suggested that EPO improves memory. This effect is independent of its effect on haematocrit [5]. Rather, it is associated with an increase in hippocampal response and effects on synaptic connectivity, neuronal plasticity, and memoryrelated neural networks. EPO may have effects on mood [6].

\section{Mechanism of action}

Erythropoietin has been shown to exert its effects by binding to the erythropoietin receptor (EpoR) [7]. EPO is highly glycosylated ( $40 \%$ of total molecular weight), with half-life in blood around five hours. EPO's half-life may vary between endogenous and various recombinant versions. Additional glycosylation or other alterations of EPO via recombinant technology have led to the increase of EPO's stability in blood (thus requiring less frequent injections). EPO binds to the erythropoietin receptor on the red cell progenitor surface and activates a JAK2 signaling cascade. Erythropoietin receptor expression is found in a number of tissues, such as bone marrow and peripheral/central nervous tissue. In the bloodstream, red cells themselves do not express erythropoietin receptor, so cannot respond to EPO. However, indirect dependence of red cell longevity in the blood on plasma erythropoietin levels has been reported, a process termed neocytolysis [8].

\section{Synthesis and regulation}

Erythropoietin levels in blood are quite low in the absence of anaemia, at around $10 \mathrm{mU} / \mathrm{ml}$. However, in hypoxic stress, EPO production may increase 1000 -fold, reaching $10,000 \mathrm{mU} /$ $\mathrm{ml}$ of blood. EPO is produced mainly by interstitial cells in the peritubular capillary bed [9] of the renal cortex. It is synthesized by renal peritubular cells in adults, with a small amount being produced in the liver [10]. Regulation is believed to rely on a feedback mechanism measuring blood oxygenation. Constitutively synthesized transcription factors for EPO, known as hypoxia-inducible factors, are hydroxylated and proteosomally digested in the presence of oxygen [11].

\section{Erythropoietin concentration in Normal and Complicated Pregnancy}

Changes in circulatory system during pregnancy affect renal function, due to physiological increase in blood volume [12].

Renal blood flow and glomerular filtration increase by 30 $50 \%$ [13], and because erythropoietin is of renal origin, EPO concentration has been proved to increase 2-4-folds in the course of pregnancy [14-17] and plateau is achieved after 20 weeks during the second trimester of pregnancy. It is believed that physiological blood dilution in pregnancy, increase in renal oxygen consumption due to intensified glomerular filtration as well as paracrine and autocrine mechanisms are likely to be responsible for increased EPO renal secretion in pregnancy [14].

Kowalska \& Maciejewski [12] stated that some authors found no correlation between EPO and haemoglobin concentration in women with normal pregnancy in the first or second trimester. Erdem et al. [18] and Toth et al. [19] stated that this phenomenon is explained by weakened EPO response to anaemia in pregnancy and its intensification in the final stage. Erdem et al. [18] noticed that pregnant women have significantly lower serum erythropoietin level compared to healthy pregnant patients. It was also found that EPO concentration in cord blood of newborn babies born by mothers with anaemia is significantly higher than in healthy women's babies.

Factually anaemia in pregnancy causes increased EPO secretion as a response to low haemoglobin concentration and ferritin deficiency [20].

Goldstein et al. [21] have indicated that acute and chronic bleedings in pregnancy as well as multiple pregnancies are associated with patient's elevated blood serum EPO concentration. The link between increased blood serum EPO concentration in pregnant women and the occurrence of preeclampsia is controversial. There are various theories explaining the correlation. One hypothesis assumes the elevated EPO concentration in the blood of patients with preeclampsia is caused by reduced renal perfusion, which results in local relative hypoxia and compensatory increase of renal EPO secretion. Another theory linked the intensified EPO secretion to anaemia which is caused by haemolysis [21,22].

According to Hershkovitz et al. [21] increased blood serum EPO concentration in these women results from reduced placental blood flow and its reduced oxygenation, which induces compensatory local EPO secretion by placenta. This mechanism is supposed to increase total EPO pool in blood serum of pregnant patients with preeclampsia [21]. But in a study conducted by Hershkovitz etal. [21], patients with preeclampsiahad statistically insignificant increase in EPO concentration compared to healthy pregnant women. Additionally, no differences were found in the level of haemoglobin and haematocrit [23].

Koupke et al. found that EPO was higher in pregnant women with preeclampsia than in healthy pregnant women, which is 
however statistically insignificant. But they found blood serum EPO concentration to negatively correlate with haematocrit value and haemoglobin concentration [24].

\section{Use of erythropoietin stimulating agents for the treatment of anaemia in pregnant women}

The most common true anaemias during pregnancy are iron and/or folate deficiency anaemia, and also congenital anaemias, such as thalassemias, may be the most frequent causes of pregnancy anaemia [25]. Haemoglobin $\mathrm{H}$ disease which is the intermediate form of alph thalassemia is usually associated with an increased severity of anaemia during pregnancy [26]. Haemoglobin level may sometimes fall to $70 \mathrm{~g} / \mathrm{L}$ or even less necessitating blood transfusions to preserve the health of the mother and the developing foetus. Preeclampsia, congestive heart failure and premature deaths are the main obstetrical complications described in pregnant women with $\mathrm{HbH}$ disease [25].

Recently, an increasing number of studies have demonstrated that treatment with erythropoietin stimulating agents (ESA) can avoid the use of blood transfusions, which has traditionally been the only available treatment for severe pregnancy-related anaemia not responding to conventional therapy.

ESAs have been employed in the treatment of pregnancy related anaemia associated with chronic renal failure, iron - deficiency resistant to supplementary therapy [27] as well as congenital haemoglobinopathies [28]. These studies demonstrated recombinant human erythropoietin (rHuEPO) therapy was effective in correcting anaemia but highlighted the need for appropriate modulation throughout pregnancy.

Indeed, ESA treatment gives several advantages over transfusion: reduced risk of infection or transfusion reaction, less transient effect and benefit for the patient, increased acceptability to patients, in particular those with religious objections to transfusion e.g Jehova's witnesses, as well as decreased blood product utilization and need for hospitalization [29-31].

\section{Conclusion}

Erythropoietin, also known as EPO, is a glycoprotein hormone that controls erythropoiesis, or red blood cell production. It is a cytokine for precursors in the bone marrow. Also called haematopoietin or haemopoietin, it is produced by interstitial fibroblasts in the kidney in close association with peritubular capillary and proximal convoluted tubule. The primary role of erythropoietin is an essential hormone for red blood cell production. Erythropoietin has its primary effect on red blood cell progenitors and precursors. Changes in circulatory system during pregnancy affect renal function, due to physiological increase in blood volume. Renal blood flow and glomerular filtration increase by $30-50 \%$, and because erythropoietin is of renal origin, EPO concentration has been proved to increase 2-4-folds in the course of pregnancy and plateau is achieved after 20 weeks during the second trimester of pregnancy.

\section{References}

1. Siren AL, Fratelli M, Brines M, Goemans C, Casagrande S, et al. (2001) Erythropoietin prevents neuronal apoptosis after cerebral ischemia and metabolic stress. Proc Natl Aca Sci USA 98(7): 4044-4049.

2. Haroon ZA, Amin K, Jiang X, Arcasoy MO (2003) A novel role for erythropoietin during fibrin-induced wound-healing response. Am J Pathol 163(3): 993-1000.

3. Ashby DR, Gale DP, Busbridge M, Murphy KA, Duncan ND, et al. (2010) Erythropoietin administration in human causes a marked and prolonged reduction in circulating hepicidin. Haematologica 95(3): 505-508.

4. Marti HH, Gassmann M, Wenger RH, Kvietikova I, Morganti-Kossmann MC, et al. (1997) Detection of erythropoietin in human liquor: intrinsic erythropoietin production in the brain. Kidney Int 51(2): 416-418.

5. Miskowiak K, O'Sullivan U, Harmer CJ (2007) Erythropoietin Enhances Hippocampal Response during Memory Retrieval in Humans. Journal of Neuroscience 27(11): 2788-2792.

6. Miskowiak KW, Favaron E, Hafizi S, Inkster B, Goodwin GM, et al. (2009) Effects of erythropoietin on emotional processing biases in patients with major depression: An exploratory fMRI study. Psychopharmacology 207(1): 133-142.

7. Middleton SA, Barbone FP, Johnson DL, Thurmond RL, You Y, et al (1999) Shared and unique determinants of the erythropoietin (EPO) receptor are important for binding EPO and EPO mimetic peptide. J Biol Chem 274(20): 14163-14169.

8. Livnah O, Johnson DL, Stura EA, Farrell FX, Barbone FP, et al. (1998) An antagonist peptide-EPO receptor complex suggests that receptor dimerization is not sufficient for activation. Nature Structural \& Molecular Biology 5(11): 993-1004.

9. Jacobson LO, Goldwasser E, Fried W, Plzak L (1957) Role of the kidney in erythropoiesis. Nature 179 (4560): 633-634.

10. Fisher JW, Koury S, Ducey T, Mendel S (1996) Erythropoietin production by interstitial cells of hypoxic monkey kidneys. British journal of haematology 95(1): 27-32.

11. Jelkmann W (2007) Erythropoietin after a century of research: younger than ever. Eur J Haematol 78(3): 183-205.

12. Kowalska-kanka A, Maciejewski T (2013) The role and regulation of secretion of erythropoietin in pregnancy. Dev Period Med 17(3): 270275 .

13. Markwitz W, Oko A, Nerek CW, wysokiegoryzyka CR, Bręborowicz GH (2006) Ośrodek Wydawnictw Naukowych. Poznań pp. 719-728.

14. Conrad KP, Benyo DF, Westerhausen-Larsen A (1996) Expression of erythropoietin by the human placenta. Faseb J 10: 760-768.

15. Nangaku M, Eckardt KU (2007) Hypoxia and the HIF system in kidney disease. J Mol Med (Berl) 85(12): 1325-1330.

16. McMullin MF, White R, Lappin $T$ (2003) Haemoglobin during pregnancy: relationship to erythropoietin and haematinic status. Eur J Haematol 71(1): 44-50.

17. Clapp JF, Little KD, Widness JA (2003) Effect of maternal exercise and fetoplacental growth rate on serum erythropoietin concentrations. Am J Obstet Gynecol 188: 1021-1025.

18. Erdem A, Arslan M, Yazici G (2002) The effect of maternal anaemia and iron deficiency on fetal erythropoiesis: comparison between serum erythropoietin, haemoglobin and ferritin levels in mothers and newborns. J Matern Fetal Neonatal Med 11: 329-332. 
19. Toth B, Fischl A, Scholz C (2008) Erythropoietin and erythropoietin receptor expression in normal and disturbed pregnancy. Eur J Obstet Gynecol Reprod Biol 140(2): 192-200.

20. Ervasti M, Kotisaari S, Heinonen S (2008) Elevated serum erythropoietin concentration is associated with coordinated changes in red blood cell and reticulocyte indices of pregnant women at term. Scand. J Clin Lab Invest 68(2): 160-165.

21. Goldstein JD, Garry DJ, Maulik D (2000) Obstetric conditions and erythropoietin levels. Am J Obstet Gynecol 182(5): 1055-1057.

22. Hershkovitz R, Ohel I, Sheizaf B (2005) Erythropoietin concentration among patients with and without preeclampsia. Arch Gynecol Obstet 273: $140-143$.

23. Koupke CJ, Vaziri ND, Powers DR (1991) Erythropoietin in preeclampsia. Obstet Gynecol 78: 795-799.

24. Galanello R, Aru B, Dessi C, Addis M, Paglietti E, et al. (1992) HbH disease in Sardina: molecular haematological and clinical aspects. Acta Haematologica 88: 1-6.

25. Chui DHK, Fucharven S, Chan V (2003) Haemoglobin H disease: not necessarily a benign disorder. Blood 101: 791-800

26. Breymann C, Major A, Ritcher C, Huch R, Huch A (1955) Recombinant human erythropoietin and parenteral iron in the treatment of pregnancy anaemia: a pilot study. Journal of Perinatal Medicine 23: 8998.

27. Breymann C, Vista E, Huch R, Huch A (2001) Efficacy and safety of intravenously administered iron in sucrose with or without adjuvant recombinant erythropoietin for the treatment of resistant iron deficiency anaemia during pregnancy. American J Obstet Gynaecol 184: 662-667.

28. Kraft A, Breymann C (2004) Haemoglobinopathy in Pregnancy: diagnosis and treatment. Current Medicinal Chemistry 11: 2903-2909.

29. Obeagu EI, Ezimah ACU, Obeagu GU (2016) Erythropoietin in the Anaemias of Pregnancy: A Review. Int J Curr Res Chem Pharm Sci 3(3): 10-18.

30. Obeagu EI (2016) Erythrocyte enumeration and serum erythropoietin in chronic kidney disease patients: A study in Federal Medical Centre, Umuahia, Nigeria. International Journal of Advanced Research in Biological Sciences 3(7): 163-170.

31. Obeagu EI, Okoroiwu II, Ezimah ACU (2016) Evaluation of serum erythropoietin levels in chronic kidney disease patients in Federal Medical centre, Umuahia, Nigeria. International Journal of Current Research in Biology and Medicine 1(4): 15-21.

\section{Your next submission with Juniper Publishers will reach you the below assets}

- Quality Editorial service

- Swift Peer Review

- Reprints availability

- E-prints Service

- Manuscript Podcast for convenient understanding

- Global attainment for your research

- Manuscript accessibility in different formats

( Pdf, E-pub, Full Text, Audio)

- Unceasing customer service

Track the below URL for one-step submission

https://juniperpublishers.com/online-submission.php 